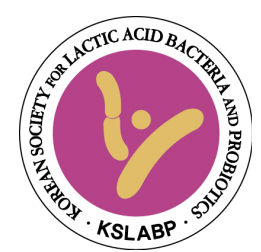

Research Article

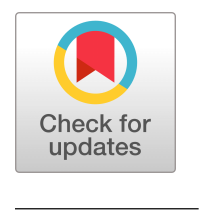

Received: Jan 29, 2019

Revised: Jun 24, 2019

Accepted: Jun 24, 2019

${ }^{*}$ Corresponding author :

Jae Hwan Kim

Neo Cremar Co., Ltd., 211,

Jungdae-ro, Songpa-gu, Seoul

05702, Korea

Tel: +82-2-401-4088,

E-mail: jayhkim@cremar.co.kr

ORCID

Jung Cheul Shin

https://orcid.org/0000-0002-1871-7670

$\mathrm{Na}$ Ri Kim

https://orcid.org/0000-0003-4102-5557

Jong Ho Koh

https://orcid.org/0000-0002-9727-8273

Jae Hwan Kim

https://orcid.org/0000-0002-4179-6530
Curr. Top. Lact. Acid Bact. Probiotics 2019;5(1):13-19

https://doi.org/10.35732/ctlabp.2019.5.1.13

ISSN 2287-853X
올리고당의 피부건강 및 피부질환 개선효과

신중철 ${ }^{1} \cdot$ 김나리 ${ }^{1} \cdot$ 고종호 ${ }^{2} \cdot$ 김재환 $^{1 *}$

${ }^{1}$ (주)네오크레마, ${ }^{2}$ 한국폴리텍대학 바이오캠펴스

\section{Improvement Effect of Skin Health and Skin Disease of Oligosaccharides}

\author{
Jung Cheul Shin ${ }^{1}$, Na Ri Kim¹, Jong Ho Koh² and Jae Hwan Kim,** \\ ${ }^{1}$ Neo Cremar Co., Ltd., ${ }^{2}$ Bio Campus of Korea Polytechnic College
}

\begin{abstract}
Oligossaccharides have beneficial effects on the immune system, atopy and skin health according to the prebiotic effect on intestinal microflora. Due to the excellent physiological functions of these oligosaccharides, the demand for prebiotics is rapidly increasing in the world. In this review, it has been shown that galactooligosaccharide(GOS) intake improves skin health and atopic eczema and fructooligosaccharide(FOS) prevent atopic dermatitis in human clinical trials. These results indicate that oligosaccharides are sufficiently applicable as a functional food for improving skin health and skin diseases.
\end{abstract}

\section{Keywords}

oligosaccharides, immune system, skin health, prebiotics, galactooligosaccharide, fructooligosaccharide

\section{서 론}

피부의 노화는 피부를 구성하는 세포들의 회복능력의 저하에 의하며, 이의 원인은 나이가 들어감에 따른 내인성 노화와 지속적인 자외선(UV) 노출에 의하여 발생하는 외인성 노화(광노화)로 분류된다. 내인성 노화의 특징은 세포수가 감소함에 따라 세포 외 기질 단백질 섬유의 합성량이 감소하고 느슨해져 탄력이 감소되고, 피부세포 내 수분 손실로 인하여 각질층 구조가 변하는 미세한 주름, 피하지방층의 감소, 피부 보습이 감소되는 임상적 특징을 가진다. 외인성 노화는 자외선의 자극으로 인하여 발생되는 활성 산소종 (ROS) 이 싸이토카인(Cytokine) 발생을 촉진시켜 굵고 깊은 주름이 발생되며, 멜라닌세포의 활성이 증가되어 불규칙한 색소침착이 발생하고, 피부가 건조해지며, 탄력성이 감소하는 증상을 나타낸다. 내인 성 또는 외인성 노화의 공통적인 요인으로써 생성되는 활성산소종이 적절하게 제거되지 못하여 피부의 회복능력을 방해하여 피부노화를 가속화시킨다는 것이다.

장은 인체 내 주요 면역기관이며, 장점막 면역계 내 면역세포 이동을 통하여 피부면역계와 연결되어

This is an Open Access article distributed under the terms of the Creative Commons Attribution Non-Commercial License (http://creativecommons.org/licenses/ by-nc/3.0) which permits unrestricted non-commercial use, distribution, and reproduction in any medium, provided the original work is properly cited 
있다. 최근 주목되고 있는 프리바이오틱 소재 중 하나가 올리고당 (Oligosaccharides)이다. 이들은 장내 유산균인 비피더스균(Bifidobacteria)이나 락토바실러스균(Lactobacilli)을 선택적으로 증 식시켜 균총 개선, 변비 개선 등 다양한 프리바이오틱스 효능을 나 타내고 있다고 알려져 있으며, 이들의 작용기전이나 유산균과의 상 호작용 연구 등 다양한 연구가 활발히 이루어지고 있다.

대표적인 올리고당인 갈락토올리고당(Galactooligosaccharide: GOS)과 프락토올리고당(Fructooligosaccharide: FOS)의 경우, 정장작용에 도움을 주며, 싸이토카인(Cytokine)의 변화를 초래하 여 피부건강을 개선할 수 있을 뿐만 아니라, 아토피(Atopy) 질환에 도 도움을 줄 수 있다고 알려져 있으며, 현재 활발한 연구가 이루어 지고 있다.

본 문헌에서는 갈락토올리고당과 프락토올리고당의 피부개선 효과 와 아토피 등 피부질환 개선 효과에 대한 인체임상시험 결과들을 소개하고, 피부건강 개선과 피부질환에 도움을 주는 프리바이오틱 스로서의 시장확장 가능성에 대하여 언급하고자 한다.

\section{갈락토올리고당(Galactooligosaccharide)}

갈락토올리고당은 모유올리고당(HMO; Human Milk Oligosaccharide)의 구성성분인 갈락토실락토스(Galactosyllactose)를 함 유하고 있는 올리고당으로서, 영유아 장내 유익균 중 대다수를 차 지하고 있는 비피더스균의 먹이로써 적용되는 적합한 올리고당으 로 알려져 있다. 갈락토올리고당은 영유아 분유에 주로 적용되고 있는 프리바이오틱스이다. Hong YH 등(2017) 은 2017년도에 30-69세 성인 84명을 대상으로 $1.0 \mathrm{~g}$ 씩 하루 2 회 총 $2.0 \mathrm{~g}$ 의 갈락 토올리고당을 12 주 동안 섭취케 한 다음, 피부수분보유량(Skin water holding capacity), 경피수분손실량(TEWL: Transepidermal Water Loss), 주름깊ㅇ(Wrinkle depth) 및 주름면적 (Total wrinkle area) 등을 측정하였다. 연구결과, 피부수분보유량 의 경우 갈락토올리고당 섭취 후 4 주(" $p<0.05), 8$ 주( $p<0.05)$, 12 주 $(p<0.001)$ 모두 대조군 대비 유의미한 결과를 확인하였 다.(Fig. 1). 경피수분손실량의 경우는 12 주차 $\left({ }^{*} p<0.05\right)$ 에서 유의 미한 결과를 확인하였다(Fig. 2), 뿐만 아니라 12 주차에 확인한 레 플리카 포토그래피(replica photography) 측정결과 또한 대조군 대비 우수한 결과를 나타내었다(Fig. 3).

Kukkonen K. 등은 2007 년도에 임신한 임산부 1,223 명으 로부터 출산된 영아들을 대상으로 갈락토올리고당의 프로바이오틱 효과를 통한 알러지 질병예방에 대한 임상시험을 수행하였다. 시험군은 임산부 610 명을 대상으로 캡슐당 Lactobacillus rhamnosus GG, $5 \times 10^{9} \mathrm{CFU}$; Lactobacillus rhamnosus

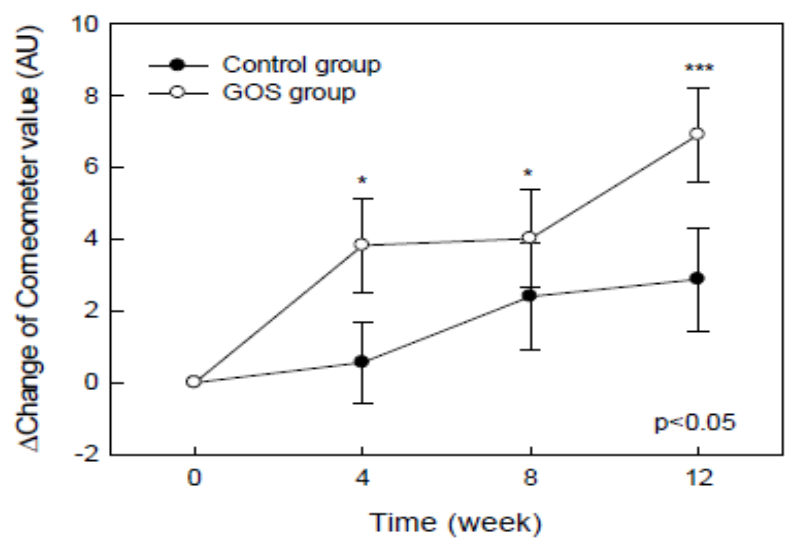

Fig. 1. 길락토올리고당의 피부 수분보유량 증가 효과.

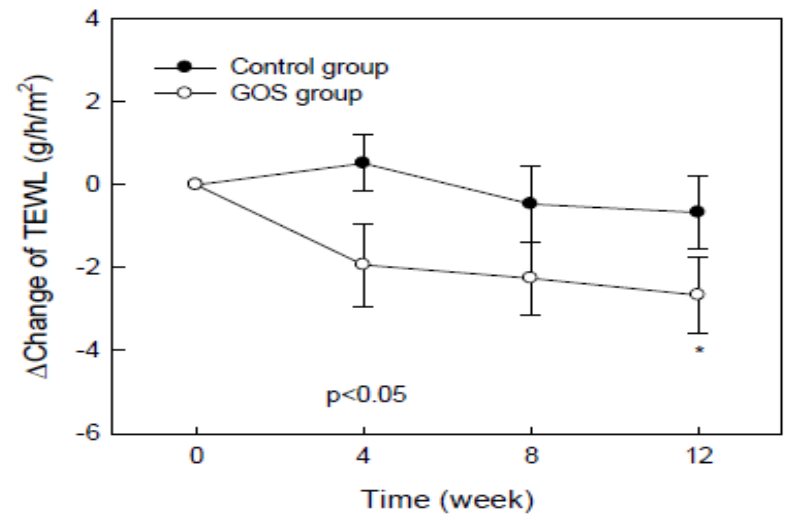

Fig. 2. 갈락토올리고당의 경표피 수분손실량 감소 효과.

LC705(DSM 7061), $5 \times 10^{9} \mathrm{CFU}$; Bifidobacterium breve $\mathrm{Bb} 99$ (DSM 13692), $2 \times 10^{8} \mathrm{CFU}$; 와 Propionibacterim freudenreichii ssp. Shermanii JS(DSM 7076), $2 \times 10^{9} \mathrm{CFU}$ 를 하루 2 회 섭취케 하고, 산모가 섭취한 유산균 캡슐을 열어 $0.8 \mathrm{~g}$ 의 갈락토올리고당이 함유된 슈가시럽 20 방울과 혼합하여 섭취한 영아군 $(n=461)$ 으로 설정하였다. 대조군은 임산부 613 명을 대상으로 셀룰로스가 함유된 캡슐을 하루 2 회 섭취토록 하였고, 산모가 섭취한 셀룰로스 함유 캡슐과 갈락토올리고당이 함유되지 않은 슈가 시럽을 섭취한 영아들(n=464)로 설정하였다.

6 개월 및 24 개월이 된 영아의 분변 내 프로바이오틱의 수를 분석한 결과, 갈락토올리고당과 유산균을 함께 섭취한 시험군의 프로바이오틱 수가 위약군 대비 유의적으로 많은 것을 확인 하였다(Table 1). IgE 감작 테스트(IgE sensitation, 양성 피부 자극 테스트: positive skin frick test response 또는 혈청항원 특이 IgE 수치: serum antigen-specific IgE level>0.7kU/L))를 


\section{(A) Control group}

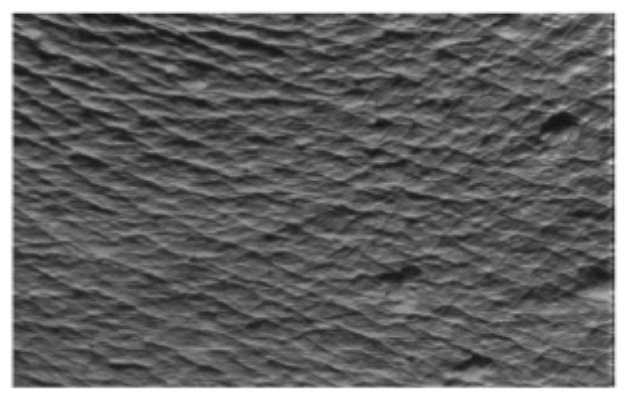

O week

\section{(B) GOS group}

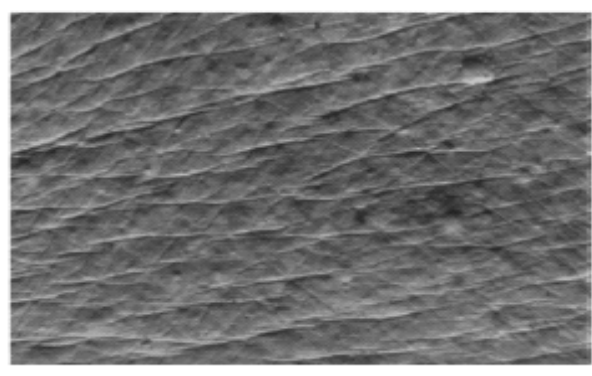

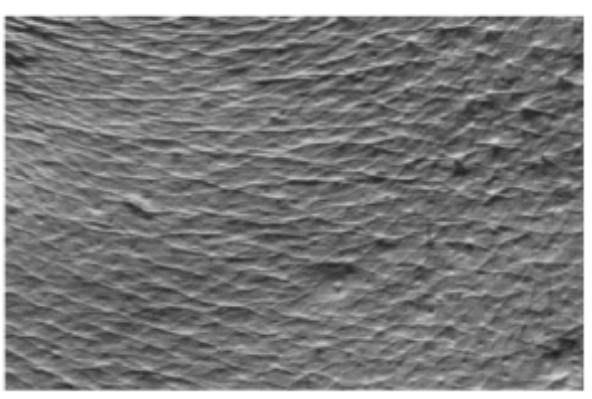

12-week

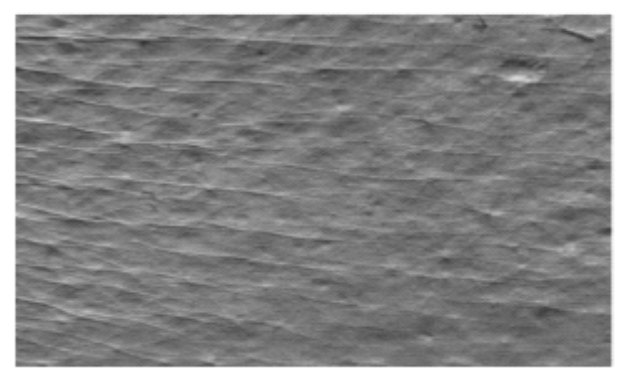

Fig. 3. 갈락토올리고당의 피부주름 개선 효과.

수행한 결과, 갈락토올리고당과 유산균을 섭취한 시험군은 위약군 대비 알러지 누적발생 에서는 영향을 미치지 않았으나, $\operatorname{IgE}$ 관련 아토피질환인 아토피성 습진(Atopic eczema)을 감소시키는 경향을 나타내었다(Table 2). 이러한 결과는 장내 프로바이오틱과 아토피질환은 밀접한 상관관계를 가지며, 프리바이오틱인 갈락토 올리고당이 장내 프로바이오틱 생존에 큰 영향을 끼친다는 것을 시사한다.

상기 문헌들은 갈락토올리고당 섭취 시 성인의 피부건강 개선과 영 유아의 피부질환 개선에 대한 연구결과이다. 문헌검색 결과, 성인 을 대상으로 아토피 등 피부질환 개선효과에 대한 인체임상을 수행 한 문헌들은 검색이 되지 않았다. 성인을 대상으로 피부질환에 대 한 추가 연구들이 진행된다면 갈락토올리고당은 피부건강 개선에 효과적인 프리바이오틱스 식품소재 외에 치료제 영역에도 진출할 가능성이 높을 것으로 기대된다.

\section{프락토올리고당}

프락토올리고당은 국내 식품공전에 의하면, 설탕분자 하나에 과당 분자가 1 3개가 결합되어 있는 단쇄 프락토올리고당이라고 정의 되어 있다. 네덜란드, 벨기에 등의 유럽에서는 치커리로부터 이눌
린을 추출하여 제조하고 있으나, 국내의 경우 설탕을 원료로 하여 제조되고 있다. 프락토올리고당의 대표적인 생리활성은 프리바이 오틱 효과이고, 영유아식 뿐만이 아니라, 다양한 식품소재로서 응 용되고 있으며, 국내에서 고시형 소재로서 건강기능식품공전에 등 재되어 있는 원료이다. 하지만 고온과 낮은 $\mathrm{pH}$ 에서 쉽게 분해되므 로 고온살균이나 낮은 $\mathrm{pH}$ 를 가지는 레토르트 나 청량음료 등에는 적용하지 않고 있다.

Reza Farid 등은 아토피질환을 가진 3개월 6세 영유아 40명을 대 상으로, 시험군은 10 억 $\mathrm{CFU}$ 프로바이오틱스와 프락토올리고당을 혼합한 분말 $1.0 \mathrm{~g}$ 씩 하루 2 회 총 $2.0 \mathrm{~g}$ 을 8 주 동안 섭취토록 하고, 위약군은 프락토올리고당과 프로바이오틱스가 없는 동일한 분말을 시험군과 동일하게 섭취토록 하였다. 아토피 피부염 중증도지수 (SCORAD ; The Severity Scoring of Atopic Dermatitis)는 첫 번 째 방문(visit 1) 4주 후 두번 째 방문(visit 2) 및 8주 후 세번 째 방문(visit 3) 시 관찰하였다. 피부염 중증도지수 측정결과, 프락 토올리고당과 프로바이오틱을 섭취한 시험군은 프로바이오틱스만 섭취한 위약군 대비, 첫 4주간(visit1-visit2) 유의적인 감소( $p=0.0$ 01 )를 나타내었고, 총 8주간 측정결과(visit1-visit3) 또한 유의적 인 감소 $(p=0.005)$ 를 나타내었다. 4 주-8주 동안은 유의적인 차이 를 나타내지는 않고 감소하는 경향을 나타내었다(Table 3). 이는 
Table 1. 갈락토올리고당과 유산균 섭취한 6 24개월 군의 분변에서의 유산균 변화

\begin{tabular}{|c|c|c|c|c|c|c|c|c|}
\hline \multirow[b]{2}{*}{ Bacterial strain } & \multirow[b]{2}{*}{ Months } & \multicolumn{4}{|c|}{ Prevalence (\%) } & \multicolumn{3}{|c|}{ Counts* } \\
\hline & & Probitics & Placebo & $\operatorname{RR}(95 \% \quad \mathrm{Cl})$ & $p$ value $^{\dagger}$ & Probitics & Placebo & $p$ value $^{\ddagger}$ \\
\hline \multirow[t]{2}{*}{ L. rhamnosus GG } & 6 & 91.3 & 23.1 & $3.96(2.39-6.55)$ & $<.001$ & $7.47(6.17-8.18)$ & $0(0-0)$ & $<.001$ \\
\hline & 24 & 41.5 & 55.3 & $0.75(0.48-1.17)$ & .195 & $0(0-5.10)$ & $3.54(0-4.99)$ & .571 \\
\hline \multirow[t]{2}{*}{ L. rhamnosus LC705 } & 6 & 54.3 & 0 & $28.3(3.98-200)$ & $<.001$ & $4.42(0-7.00)$ & $0(0-0)$ & $<.001$ \\
\hline & 24 & 24.4 & 16.7 & $1.46(0.64-3.36)$ & .336 & $0(0-3.32)$ & $0(0-0)$ & .288 \\
\hline \multirow[t]{2}{*}{ Propionibacterium JS } & 6 & 55.3 & 3.8 & $14.4(3.61-57.3)$ & $<.001$ & $3.74(0-5.98)$ & $0(0-0)$ & $<.001$ \\
\hline & 24 & 14.6 & 12.5 & $1.17(0.41-3.35)$ & .769 & $0(0-0)$ & $0(0-0)$ & .966 \\
\hline \multirow[t]{2}{*}{ Bifidobacteria total } & 6 & 97.9 & 86.5 & $1.13(1.01-1.27)$ & .039 & $9.3(8.76-9.77)$ & $8.5(7.12-9.40)$ & 0.001 \\
\hline & 24 & 90.2 & 97.9 & $0.92(0.83-1.03)$ & .117 & $8.53(8.00-8.89)$ & $8.06(7.40-8.98)$ & .338 \\
\hline \multirow[t]{2}{*}{ Lactobacilli total } & 6 & 97.9 & 55.8 & $1.75(1.37-2.24)$ & $<.001$ & $7.84(6.92-8.45)$ & $4.44(0-7.78)$ & $<.001$ \\
\hline & 24 & 70.7 & 72.9 & $0.97(0.75-1.26)$ & .819 & $4.94(0.0-6.42)$ & $4.29(0.0-5.34)$ & .318 \\
\hline
\end{tabular}

Values in boldface are statistically significant.

$\mathrm{RR}$, risk ratio.

"Values less than the detection limit of 2.7 equal 0 .

${ }^{\dagger} \chi^{2}$ test.

${ }^{\ddagger}$ Mann-Whitney $U$ test.

Table 2. 출생 후 6 개월 동안 프로바이오틱스와 갈락토올리고당을 섭취한 영아 2세 나이의 알러지질환 발생율 및 아토피성 습진 변화

\begin{tabular}{|c|c|c|c|c|c|c|c|c|}
\hline & \multicolumn{2}{|c|}{ Probiotic } & \multicolumn{2}{|c|}{ Placebo } & \multicolumn{2}{|c|}{ Unadjusted } & \multicolumn{2}{|c|}{ Adjusted $^{*}$} \\
\hline & $\mathrm{n}$ & $\%$ & $\mathrm{n}$ & $\%$ & $\mathrm{OR}(95 \% \mathrm{Cl})$ & $p$ value $^{\dagger}$ & $\mathrm{OR}(95 \% \mathrm{Cl})$ & $p$ value $^{\dagger}$ \\
\hline \multicolumn{9}{|l|}{ Primary outcome } \\
\hline Allergic disease ${ }^{\ddagger}$ & $145 / 461$ & 31.5 & $163 / 464$ & 35.1 & $0.85(0.64-1.12)$ & .236 & $0.82(0.61-1.08)$ & .159 \\
\hline IgE-associated allergic diseases ${ }^{\S}$ & $64 / 456$ & 14. & $87 / 463$ & 18.8 & $0.71(0.50-1.00)$ & .052 & $0.65(0.45-0.94)$ & .022 \\
\hline \multicolumn{9}{|l|}{ Secondary outcome } \\
\hline Eczema & $120 / 461$ & 26.0 & $15 / 464$ & 32.3 & $0.74(0.55-0.98)$ & .035 & $0.69(0.52-0.93)$ & .015 \\
\hline Atopic exzema $\|$ & $57 / 459$ & 12.4 & $82 / 463$ & 17.7 & $0.66(0.46-0.95)$ & .025 & $0.61(0.42-0.90)$ & .012 \\
\hline Sensitization & $127 / 454$ & 28.0 & $144 / 462$ & 31.2 & $0.86(0.65-1.14)$ & .289 & $0.82(0.61-1.10)$ & .0184 \\
\hline
\end{tabular}

Values in boldface are statistically significant.

"Adjusted by means of multivariable losistic regression for sex, delivery by means of cesarean section, breast-feeding for at least 6 months, use of antibitics during the intervention, and regular (daily or $\geq 2$ days a week) use of probitics after the interventions.

${ }^{\dagger}$ The $p$ value was calculated by using logistic regression analysis.

${ }^{\dagger}$ Food allergy, eczema, asthma, or allergic rhinitis.

${ }^{\S}$ Food allergy, eczema, asthma, or allergic rhinitis in infants with positive skin prick test responses or antigen-specific lgE levels of greater than $0.7 \mathrm{kU} / \mathrm{L}$.

"Eczema in infants with positive skin prick test responses or serum antigen-specific lg $\mathrm{E}$ levels of greater than $0.7 \mathrm{kU} / \mathrm{L}$.

IPositive skin prick test response or serum antigen lgE level of greater than $0.7 \mathrm{kU} / \mathrm{L}$. 
프리바이오틱인 프락토올리고당과 프로바이오틱 섭취 시 피부염 완화 효과가 첫 4주간 가장 높고, 이 후 천천히 추가 완화가 진행되 는 것을 의미한다.

프락토올리고당과 프로바이오틱 섭취시 싸이토카인인 $\gamma$-interferon, Interleukin 4 측정시 유의적인 변화는 관찰되지 않았다 (Table 4). 실험결과는 2003년 Rosentfeldt 등의 연구인 “ Effect of probiotic Lactobacillus strains on the development of eczema” 와 유사한 연구내용을 포함하고 있는데, 싸이토카인의 변화를 관찰하기 위해서는 8주 이상의 섭취를 통하여 싸이토카인 변화를 확인하는 연구를 추가 진행할 필요가 있다고 판단된다. 상기 문헌은 프락토올리고당 섭취 시 아동의의 피부질환 개선에 대 한 연구결과이다. 문헌 검색결과 프락토올리고당을 이용하여 성인 을 대상으로 수행한 피부질환 및 피부건강에 대한 연구는 검색되지 않았다. 성인을 대상으로 추가 연구가 진행된다면, 프락토올리고당 역시 프리바이오틱스 식품소재 외에 치료제 영역에도 진출할 가능 성이 높을 것으로 기대된다.

\section{갈락토올리고당과 프락토올리고당}

영유아식에 적용되고 있는 올리고당은 모유성분으로 알려진 갈락 토실락토스(galactosyllatose) 등의 단쇄올리고당(short chain oligosaccharides)을 함유하고 있는 갈락토올리고당과 프락토올 리고당을 9:1로 혼합하여 적용되는 경우가 있는데, 이는 프리바이 오틱스의 생리활성을 가지는 모유올리고당(Human Milk Oligosaccharides)의 구성당은 대부분 단쇄올리고당으로 되어 있기 때 문이다. 상기에서 언급한 바와 같이 최근에는 갈락토올리고당과 프
락토올리고당은 아토피와 같은 피부질환과 피부건강에 효과가 있 는 것으로 연구되고 있고, 이들이 혼합된 프리바이오틱스를 이용한 피부질환 감소와 알러지에 대한 연구들도 활발히 진행되고 있다. Ivakhnenka O. S. 등은 2013년도에 모유를 수유한 영아 80명, 갈락토올리고당과 프락토올리고당이 $90: 10(8 \mathrm{~g} / \mathrm{L})$ 비율로 첨가된 분유를 섭취한 영아 80 명, 표준조제분유만 섭취케 한 영아 80 명 등 총 240 명을 대상으로 최소 2 개월간 연구를 수행하였다. 연구결 과, 모유만 섭취한 영아군과 갈락토올리고당과 프락토올리고당이 첨가된 분유를 섭취한 영아군의 분변에서 비피도박테리아와 락토 바실리 의 농도가 서로 유사하였고(Table 5), 갈락토올리고당과 프 락토올리고당이 첨가된 분유를 섭취한 군은 표준조제분유만 섭취 한 군보다 식품에 대한 알러지 반응이 유의적으로 낮은 것으로 확 인되었다(Table 6). 이러한 결과는 여러 연구에서 밝혀진 바와 같 이 갈락토올리고당과 프락토올리고당은 영아의 장내 균총 개선에 기여하며, 이를 통해 면역체계를 통한 피부질환 개선 활성을 가진 다는 것을 시사한다고 할 수 있다.

\section{결 론}

올리고당류는 프리바이오틱 효과를 기반으로 정장작용 뿐만 아니 라, 피부수분보유량, 경피수분손실량, 주름, 아토피 등 다양한 피부 건강 및 피부질환 개선에 대한 기능을 보유하고 있는 것이 밝혀지 고 있다. 하지만 성인을 대상으로 연구된 결과들이 많지 않아, 이너 뷰티 관련 식품시장과 피부질환 치료제 또는 치료 보조제 시장형성 이 초기단계에 머물러 있는 상황이다, 추가연구로서 인체 임상 및 작용기전 연구들을 수행하여, 정장작용 시장에 머물러 있는 올리고

Table 3. 프락토올리고당 섭취기간에 따른 아토피피부염증 중증도 지수 변화

\begin{tabular}{ccccccc}
\hline SCORAD & $\begin{array}{c}\text { Control group } \\
\text { Mean(SD) }\end{array}$ & $95 \%$ Confidence interval & $\begin{array}{c}\text { Study group } \\
\text { Mean(SD) }\end{array}$ & $95 \%$ Confidence interval & $F$ & $p$ value \\
\hline Visit 1 and 2 & $-11.06(10.96)$ & $-14.05-(-9.15)$ & $-29.51(19.09)$ & $-33.78-(-25.24)$ & 12.6 & 0.001 \\
Visit 1 and 3 & $-20.10(8.63)$ & $-22.3-(-18.07)$ & $-39.2(24.22)$ & $44.61-(-33.79)$ & 8.94 & 0.005 \\
Visit 2 and 3 & $-7.65(8.33)$ & $-9.58-(5.72)$ & $-9.4(11.14)$ & $-11.89-(-6.91)$ & 0.22 & 0.6 \\
\hline
\end{tabular}

SCORAD:severity scoring of atopic dermatitis.

Table 4. 프락토올리고당 섭취 전 후의 싸이토카인 변화

\begin{tabular}{ccccccc}
\hline Cytokines & $\begin{array}{c}\text { Control group } \\
\text { Mean(SD) }\end{array}$ & $\begin{array}{c}\text { Study group } \\
\text { Mean(SD) }\end{array}$ & D & 95\% Confidence interval & $t \quad p$ value \\
\hline Interleukin 4 & $0.33(2.60)$ & $0.83(1.26)$ & 0.05 & $0.05-1.31$ & 0.85 \\
$\gamma$-Interferon & $153.33(509.33)$ & $77.70(225.94)$ & -75.63 & $-75.63-256.21$ & 0.47 & 0.6 \\
\hline
\end{tabular}


Table 5. 분변 내 유산균 변화

\begin{tabular}{ccccc}
\hline & $\begin{array}{c}\text { Group 1 } \\
\text { (breast feeding) }\end{array}$ & (formular with scGOS/lcFOS) & $\begin{array}{c}\text { Group 4 } \\
\text { (standard formular) }\end{array}$ & $p$ \\
\hline Bifidobacteria(CFU/g) & $9.047(1.075)$ & $8.92(1.011)$ & $7.81(0.83)$ & $<0.05$ \\
Lactobacilli(CFU/g) $^{*}$ & $7.26(0.65)$ & $7.22(0.74)$ & $6.81(0.93)$ & $<0.05$ \\
\hline
\end{tabular}

"mean, SD in brackets.

Table 6. 생후 18 개원동안의 알러지 반응빈도

\begin{tabular}{lcccc}
\hline & Group 1(n=51) & Group 2(n=62) & Group 3(n=53) & $p$ \\
\hline Allergic reactions to food $^{*}$ & $3.92(2)$ & $4.84(3)$ & $16.98(9)$ & $<0.05$ \\
Allergic reactions to caw's milk proteins $^{*}$ & $1.96(1)$ & $3.23(2)$ & $15.09(8)$ & $<0.05$ \\
AD $^{*}$ & $3.92(2)$ & $4.84(3)$ & $16.98(9)$ & $<0.05$ \\
Respiratory system allergic symtoms* & $1.96(1)$ & $4.84(3)$ & $13.21(7)$ & $<0.05$ \\
Gastro-intestinal symtoms of food allergy & $1.96(1)$ & $3.23(2)$ & $13.21(7)$ & $<0.05$ \\
\hline
\end{tabular}

percentage, number of children in brackets.

당 시장을 이너뷰티, 화장품 및 피부질환 시장으로의 개척이 필요 한 시점이다.

\section{References}

1. Aachary AA, and Prapulla SG (2011) Xylooligosaccharides (XOS) as an emerging prebiotic: microbial synthesis, utilization, structural characterization, bioactive properties, and applications, Compre. Rev. Food. Sci. Food Saf. 10(1), 2.

2. Choi EH (2016) Molecular Mechanisms of Skin Aging and Age-related Diseases, ed. T. Quan, 61, CRC Press, New York Washington, D.C..

3. Park S, and Shim JH (2016) Anti-aging effect of psoraleae fructus extract in UVA-irradiated HaCaT cells, AJBC. 14(2), 119.

4. Egawa M, Oguri M, Kuwahara T, and Takahashi M (2002) Effect of exposure of human skin to a dry environment, Skin. Res. Technol. 8(4), 212.

5. Farnworth ER (2016) Handbook of Nutraceuticals and Functional Foods, ed. E. C. Wildman, 335, CRC Press, New York Washington, D.C..

6. Collins S, and Reid G (2016) Distant site sffects of ingested prebiotics, Nutrients 8(9), 523.

7. Kober MM, and Bowe WP (2015) The effect of probiotics on immune regulation, acne, and photoaging, IJWD 1(2), 85.

8. Hong YH, Chang UJ, Kim YS, Jung EY, and Suh HJ (2017) Dietary galactooligosaccharides improve skin health: A randomized double blind clinical trials. Asia Pac. J. Clin. Nutr. 26(4), 613-618.

9. Suh YS, and Kim JH (2015) Oligosaccharides oroperties, Curr. Top. Lactic Acid Bac. Probio. 3(2), 62-69.

10. Farid R, Ahanchian H, Jabbari F, and Moghiman T (2011) Effect of a new synbiotic mixture on atopic dermatitis in children: A randomized- controlled trial. Iran J. Pediatr. 21(2), 225-230.

11. Jung EY, Kwon JI, Hong YH, and Suh HJ (2017) Evaluation of anti-Wrinkle effects of DuOLIGO, composed of lactulose amd galactoligosaccharides, Prev. Nutr. Food Sci. 22(4), 381-384.

12. Niittynen L, Kajander K, and Korpela R (2007) Galactooligosaccharides and bowel function. Scandinavian Journal of Food and Nutrition 51(2), 62-66.

13. Kukkonen K, Savilahti E, Haahtela T, JuntunenBackman K, Korpela R, Poussa T, Tuure T, and 
Kuitunen M (2007) Probiotics and prebiotic galactooligosaccharides in the prevention of allergic diseases: A randomized, double-blind, placebo-controlled trial. J. Allergy Clin. Immunol. 119(1), 192-198.

14. Thongaram T, Hoeflinger JL, Chow J, and Miller MJ (2017) Prebiotic galactooligosaccharide metabolism by probiotic lactobacilli and bifidobacteria. J. Agric. Food Chem. 65, 4184-4192.

15. Kim HJ, Lee SH, Go HN, Ahn JR, Kim HJ, and Hong SJ (2018) Effects of kestose on gut mucosal immunity in an atopic dermatitis mouse model. Journal of Dermatological Science 89, 27-32.

16. Weise C, Ernst D, Tol EAFV, and Worm M (2013) Dietary polyunsaturated fatty acids and non-digestible oligosaccharides reduce dermatitis in mice. Pediatric Allergy and Immunology 24, 361-367.

17. Collins S, and Reid G (2016) Ristant site effects of ingested prebiotics. Nutrients 8, 523 .

18. Hendaus MA, Jomha FA, and Ehlayel M (2016) Allergic diseases among children: nutritional prevention and intervention. Therapeutics and Clinical Risk Management 12, 362-372.

19. Sierra C, Mar 1'a-Jose' Bernal, Javier Blasco, Rosario Mart 1 'nez, Jaime Dalmau, Inmaculada Ortun o, Beatriz Esp 1'n, Mar 1'a-Isabel Vasallo, David Gil, Mar 1 'a-Luisa Vidal, Da' maso Infante, Rosaura Leis and Jose' Maldonado (2015) Prebiotic effect during the first year of life in healthy infants fed formula containing GOS as the only prebiotic: a multicentre, randomised, double-blind and placebocontrolled trial. Eur. J. Nutr. 54, 89-99.

20. Moro G, Arslanoglu S, Stahl B, Jelinek J, Wahn U, and Boehm GA (2006) mixture of prebiotic oligosaccharides reduces the incidence of atopic dermatitis during the first six months of age. Arch Dis Child. 91, 814-819.

21. Ranucci G, Buccigrossi V, Borgia E, Piacentini D, Visentin F, Cantarutti L, Baiardi P, Felisi M, Spagnuolo MI, Zanconato S, Baraldi E, Giaquinto C, and Guarino A (2018) Galacto-oligosaccharide/ polidextrose enriched formula protects against respiratory infections in infants at high risk of atopy: A randomized clinical trial. Nutrients 10, 286.

22. Ivakhnenko OS, and Nyankovskyy SL (2013) Effect of the specific infant formula mixture of oligosaccharide s on local immunity and development of allergic and infectious disease in young children: randomized study, Pediatriapolska 88, 398-404.

23. Rosenfeldt V, Benfeldt E, Nielsen SD et al. (2004) Lactobacillus GG effect in increasing IFN-gamma production in infant with cow's milk allergy. Allergy Clin. Immunol. 114(1), 131-136.

24. 식품공전.

25. 건강기능식품공전. 